\title{
The effect of kaolin modification of silane coupling agents on the properties of the polyethylene composites
}

\author{
Ludwik Domka1, Adrianna Malicka ${ }^{1,2}$, Natalia Stachowiak ${ }^{1}$ \\ ${ }^{1}$ A. Mickiewicz University, Department of Metalorganic Chemistry, Poznań, Poland \\ ${ }^{2}$ A. Mickiewicz University, Department of Macromolecular Physics, Poznań, Poland \\ e-mail:domkal@amu.edu.pl; malicka@amu.edu.pl; natara@tlen.pl
}

\begin{abstract}
This paper shows the results of using the modified kaolin by silane coupling agents in HDPE composite and the effect of surface modifications of fillers on the properties of polyethylene composites. In the first stage pure and modified kaolin was subjected to a number of tests in order to determine the backfill density, water and paraffin oil absorbability, the surface area and pore volume, the morphology of their grains, thermal analysis and the FT-IR spectroscopy.

In the second stage the composites, which were moulded into the samples that could be subjected to further tests, were produced. The samples were characterised by the determination of the hardness according to Shore, the elasticity modulus, the tensile strength and tearing strength.

The modification of the kaolin surface has resulted in a substantial improvement of the strength parameters of the obtained polyethylene composites.
\end{abstract}

Keywords: kaolin/HDPE composites, modified fillers, silane coupling agents.

\section{INTRODUCTION}

Kaolin is a mineral filler of natural origin most often used in the production of plastic and elastomer materials. The composites obtained after their introduction into the polymer matrix are characterised by the improved strengthening physical properties ${ }^{1}$. One of the main components of kaolin is the mineral kaolinite, being hydrated aluminium silicate of the formula: $\mathrm{Al}_{2} \mathrm{O}_{3} \cdot 2 \mathrm{SiO}_{2} \cdot 2 \mathrm{H}_{2} \mathrm{O}$. Kaolinite is 1:1 dioctahedral clay mineral composed of structurally asymmetric layers. One side of the layer is gibbsite-like with aluminium atoms coordinated octahedrially with applied oxygen atoms and hydroxyls. The other side of the layer is constituted by the silicate layer structure, where the silicon atoms are coordinated thetrahedrially to oxygen ${ }^{2}$. At the interface of each group of the layers there are hydroxyl groups. Three fourth of the $\mathrm{OH}^{-}$groups being the external hydroxide groups are at the surface of a kaolinite packet and their protons take part in hydrogen bonds of the lengths of 3.13, 3.00 and $2.29 \AA$. The other $\mathrm{OH}^{-}$groups are inside the packet; they are called the internal hydroxyl groups, and are involved in the shortest hydrogen bonds of $2.96 \AA$. Hydrogen bond formation changes the polarization of the $\mathrm{OH}$ bonds so that the positive charge is shifted towards the protons ${ }^{3}$. The lamellar structure of the kaolinite is responsible for their excellent cleavage and easy separability into thin sheets. The lamellar packets are electrically neutral. The packets are linked through the hydrogen bonds made with the involvement of the hydroxyl groups coordinated about a single packet and about the silica atoms in the neighbouring packet ${ }^{4}$. The paper reports on the production of kaolin filled polymers, their characterisation and the effects of the kaolin modifications with silane coupling agents significantly improving the strength of the composites.

\section{EXPERIMENTAL}

\section{Substrates}

The KOG kaolin from the Surmin-Kaolin mine in Nowogrodziec near Bolesławiec was used. The kaolin surface was modified with the following silane -coupling agents made by Unisil, Tarnów:

-3-isocyanatepropyltrimethoxysilane 3iso

- 3-aminopropyltrietoxysilane 3A

- N-2-aminoethyl 3-aminopropyltrimethoxysilane N2

- Vinyltriethoxysilane $\mathbf{V}$

- 3-methacryloxypropyltrimetoxysilane $\mathbf{M}$

- 3-chloropropyltrimethoxysilane $\mathbf{C h}$

\section{Modification of fillers}

The surface modification was performed at room temperature in a 1:1 water-ethanol solution with a $1-3 \%$ vol addition of the silane coupling agent, in the MPW-309 mixer until the plastification of the plastic solid. The airdried sample was ground in the mortar and sieved through a mesh size $0.063 \mathrm{~mm}$.

\section{Filler testing}

Pure and modified kaolin was subjected to a number of tests in order to determine their bulk density PN-80/C04404/03, water ${ }^{5}$ and paraffin oil absorbability PN-87/C$04404 / 1$. The surface area and pore volume distribution were determined on the ASAP 2010 Sorptometer and the SEM photographs of the samples were taken to assess the morphology of their grains by the PHILIPS SEM 515. The gravimetric measurements (TG, DTG, DTA methods) were determined on a thermogravimeter Setaram $\mathrm{TGA}^{6}$. The IR spectra were taken on the Bruker FT-IR IFS 66/s spectrometer.

\section{Composite preparation}

Polyethylene Hostallen ACP 5831 D made by Basell Orlen Polyolefins was selected because of a wide range of applications for the production of objects that have to 
Table 1. The absorbing capacities and the bulk density of kaolins

\begin{tabular}{|l|c|c|c|}
\hline \multicolumn{1}{|c|}{ Type of the filler } & $\begin{array}{c}\text { Water absorbing } \\
\text { capacity } \\
{\left[\mathrm{cm}^{3} / 100 \mathrm{~g}\right]}\end{array}$ & $\begin{array}{c}\text { Paraffin oil } \\
\text { absorbing capacity } \\
{\left[\mathrm{cm}^{3} / 100 \mathrm{~g}\right]}\end{array}$ & $\begin{array}{c}\text { Bulk density } \\
{\left[\mathrm{g} / \mathrm{cm}^{3}\right]}\end{array}$ \\
\hline Pure kaolin & $150 \pm 50$ & $50 \pm 50$ & $1.56 \pm 0.01$ \\
\hline $\begin{array}{l}\text { Kaolin modified with } \\
\text { 3-isocyanatepropyltrimethoxysilane }\end{array}$ & $160 \pm 50$ & $200 \pm 50$ & $1.68 \pm 0.01$ \\
\hline $\begin{array}{l}\text { Kaolin modified with } \\
\text { 3-aminopropyltrietoxysilane }\end{array}$ & $200 \pm 50$ & $220 \pm 50$ & $1.70 \pm 0.01$ \\
\hline $\begin{array}{l}\text { Kaolin modified with } \\
\text { N-2-aminothyl } \\
\text { 3-aminopropyltrimethoxysilane }\end{array}$ & $250 \pm 50$ & $250 \pm 50$ & $1.73 \pm 0.01$ \\
\hline Kaolin modified with vinyltriethoxysilane & $300 \pm 50$ & $90 \pm 50$ & $1.78 \pm 0.01$ \\
\hline $\begin{array}{l}\text { Kaolin modified with } \\
\text { 3-methacryloxypropyltrimetoxysilane }\end{array}$ & $400 \pm 50$ & $100 \pm 50$ & $1.84 \pm 0.01$ \\
\hline $\begin{array}{l}\text { Kaolin modified with } \\
\text { 3-chloropropyltrimethoxysilane }\end{array}$ & $390 \pm 50$ & $70 \pm 50$ & $1.89 \pm 0.01$ \\
\hline
\end{tabular}

show high mechanical strength. The composites with the modified fillers were produced at the Institute of Plastics Processing „Metalchem” in Toruń, using a screw extruder BTSK 20/40D made by Bühler. There were $4 \%$ of fillers in the composites. The composites were moulded into the samples that could be subjected to further tests.

\section{Composite testing}

The samples were characterised by the hardness according to the Shore scale PN-80C/04238, the PN-EN ISO $527 / 1998$ elasticity modulus, the tensile strength and tearing strength at the TIRA test 27025 stand PN-EN ISO $527 / 1998$.

\section{RESULTS AND DISCUSSION}

Table 2. The surface area of kaolins

\begin{tabular}{|l|c|}
\hline Type of the filler & Surface area BET $\left[\mathrm{m}^{2} / \mathrm{g}\right]$ \\
\hline Pure kaolin & $10.85 \pm 0.06$ \\
\hline $\begin{array}{l}\text { Kaolin modified with } \\
\text { 3-chloropropyltrimethoxysilane }\end{array}$ & $11.67 \pm 0.06$ \\
\hline $\begin{array}{l}\text { Kaolin modified with } \\
\text { 3-isocyanatepropyltrimethoxysilane }\end{array}$ & $12.32 \pm 0.08$ \\
\hline $\begin{array}{l}\text { Kaolin modified with } \\
\text { 3-aminopropyltrietoxysilane }\end{array}$ & $12.43 \pm 0.06$ \\
\hline $\begin{array}{l}\text { Kaolin modified with } \\
\text { N-2-aminoethyl } \\
\text { 3-aminopropyltrimethoxysilane }\end{array}$ & $12.67 \pm 0.08$ \\
\hline $\begin{array}{l}\text { Kaolin modified with } \\
\text { vinyltriethoksysilane }\end{array}$ & $15.49 \pm 0.09$ \\
\hline $\begin{array}{l}\text { Kaolin modified with } \\
\text { 3-methacryloxy } \\
\text { propyltrimetoxysilane }\end{array}$ & $16.60 \pm 0.09$ \\
\hline
\end{tabular}

Table 3. The pore size of kaolins

\begin{tabular}{|l|c|}
\hline \multicolumn{1}{|c|}{ Type of the filler } & Pore size [nm] \\
\hline Pure kaolin & $11.204 \pm 0.001$ \\
\hline $\begin{array}{l}\text { Kaolin modified with } \\
\text { 3-chloropropyltrimethoxysilane }\end{array}$ & $9.854 \pm 0.001$ \\
\hline $\begin{array}{l}\text { Kaolin modified with N-2 aminoethyl- } \\
\text { 3-aminopropyltrimethoxysilane }\end{array}$ & $9.755 \pm 0.001$ \\
\hline $\begin{array}{l}\text { Kaolin modified with } \\
\text { 3-aminopropyltriethoxysilane }\end{array}$ & $9.569 \pm 0.001$ \\
\hline $\begin{array}{l}\text { Kaolin modified with } \\
\text { 3-isocyanatepropyltrimethoxysilane }\end{array}$ & $9.506 \pm 0.001$ \\
\hline Kaolin modified with vinyltriethoxysilane & $7.647 \pm 0.001$ \\
\hline $\begin{array}{l}\text { Kaolin modified with } \\
\text { 3-methacryloxypropyltrimethoxysilane }\end{array}$ & $6.980 \pm 0.001$ \\
\hline
\end{tabular}

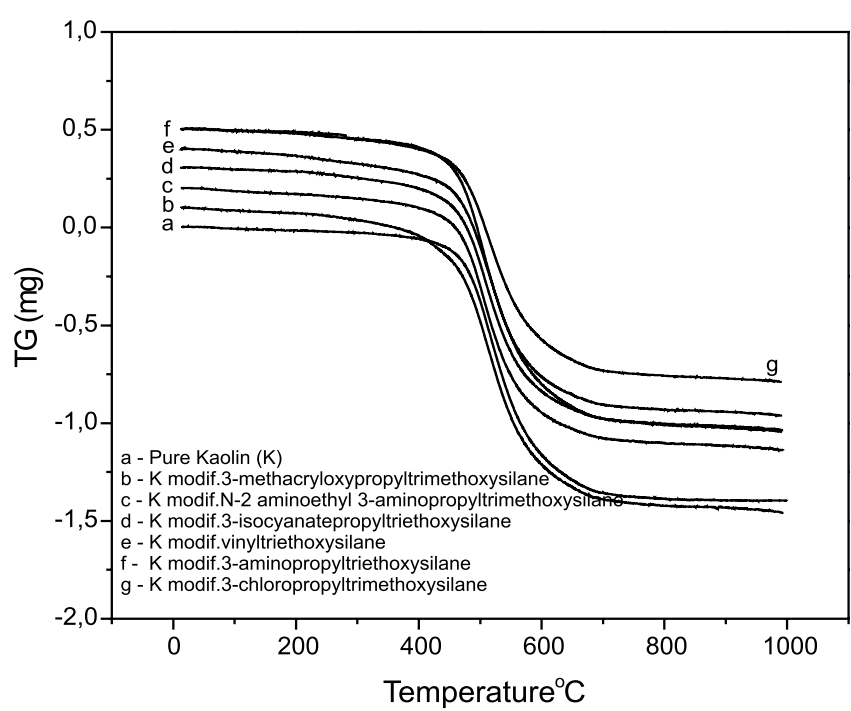

Figure 1. The TG-Thermogravimetric curves of the kaolin samples

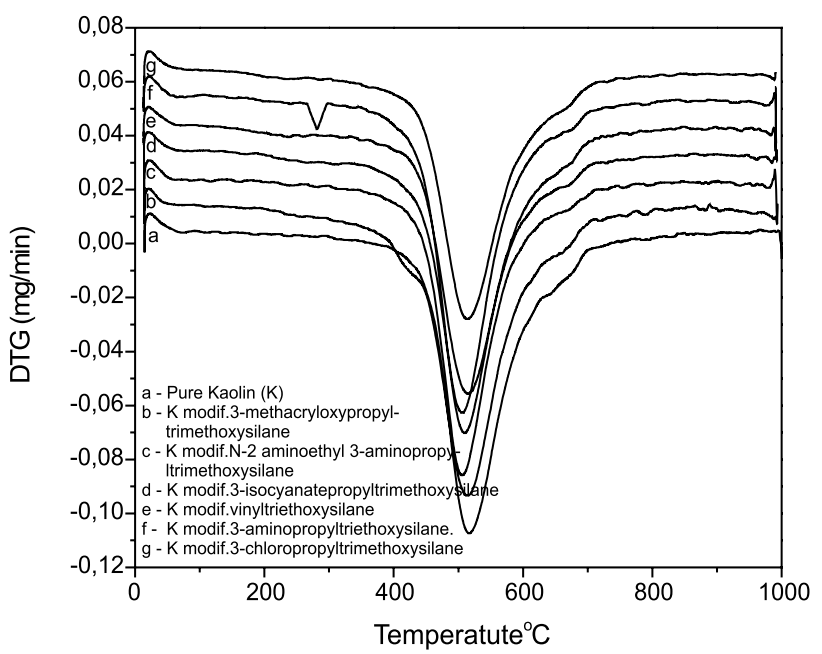

Figure 2. The DTG-Thermogravimetric curves of the kaolin samples

The modification of kaolin with silane coupling agents significantly improves the physicochemical parameters of the mineral fillers (Tables $1-3$ ).

The surface area increased, the pore sizes are reduced, the bulk density increases and the

hydrophilous-hydrophobic properties were improved. The obtained fillers are characterised by significant thermal stability (Figs. 1 - 4).

On heating the samples release the water that can originate from the following: 


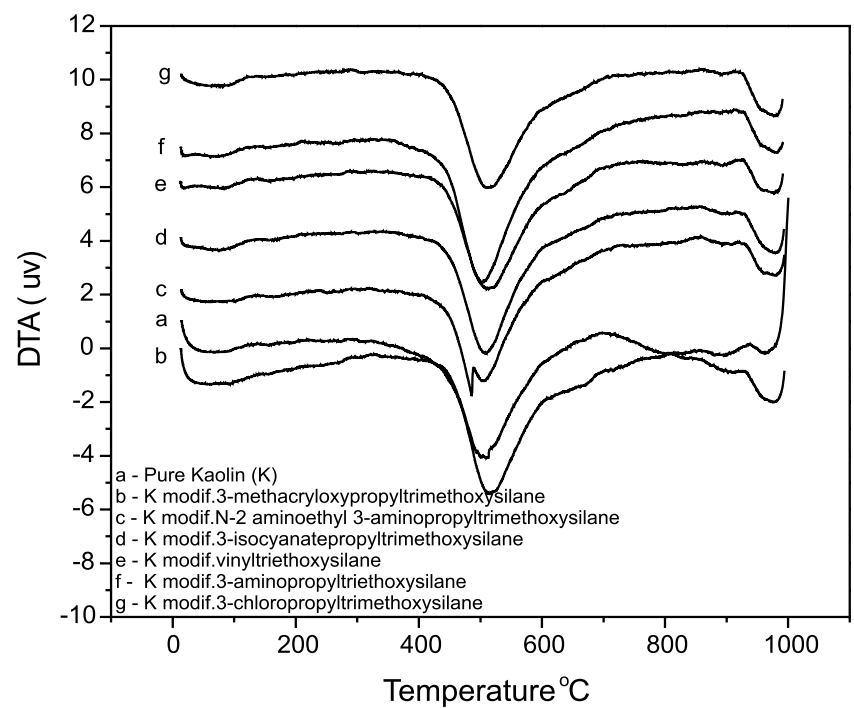

Figure 3. The DTA curves of the kaolin samples

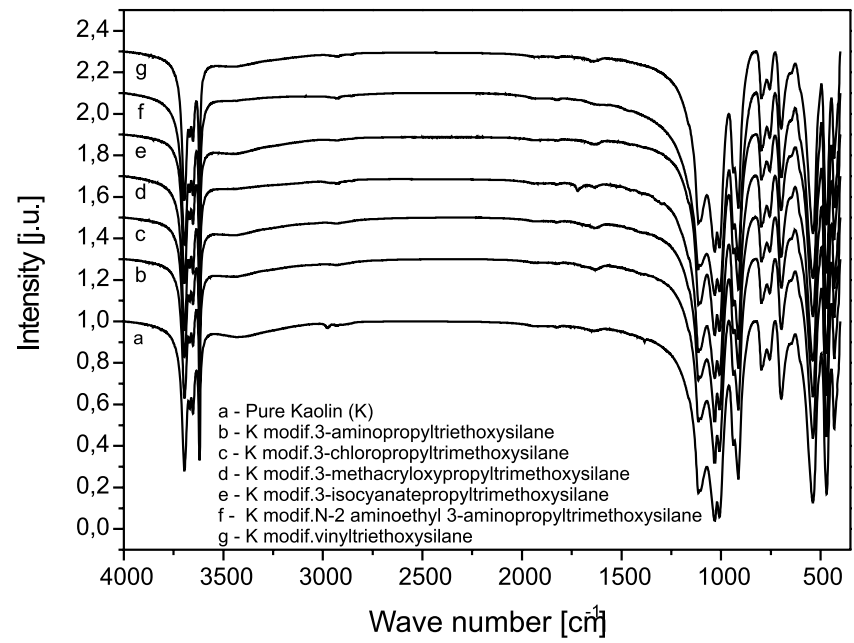

Figure 4. The FT-IR spectrum of kaolins in the range of $4000-400 \mathrm{~cm}^{-1}$

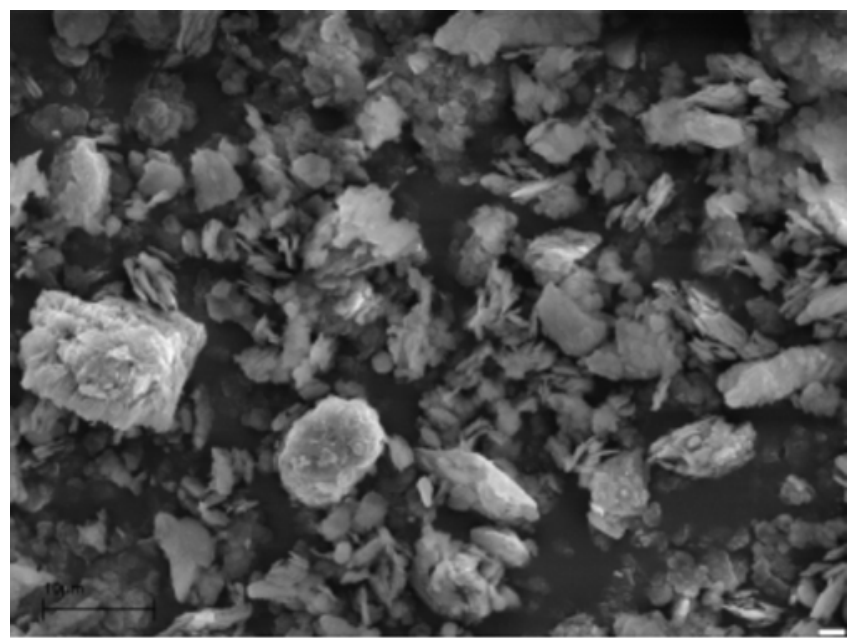

Scale $10000: 1$

Photo 1. Pure kaolin mined in KOG „Surmin-Kaolin” in Nowogrodziec

- the multilayer adsorbed water that can be released at $125^{\circ} \mathrm{C}$

- the monolayer adsorbed water released completely above $250^{\circ} \mathrm{C}$

- the water liberated in the process of the decomposition of the organic compounds of lignin and tannin, making about $0.05-1.8 \%$ of the water contained in kaolin

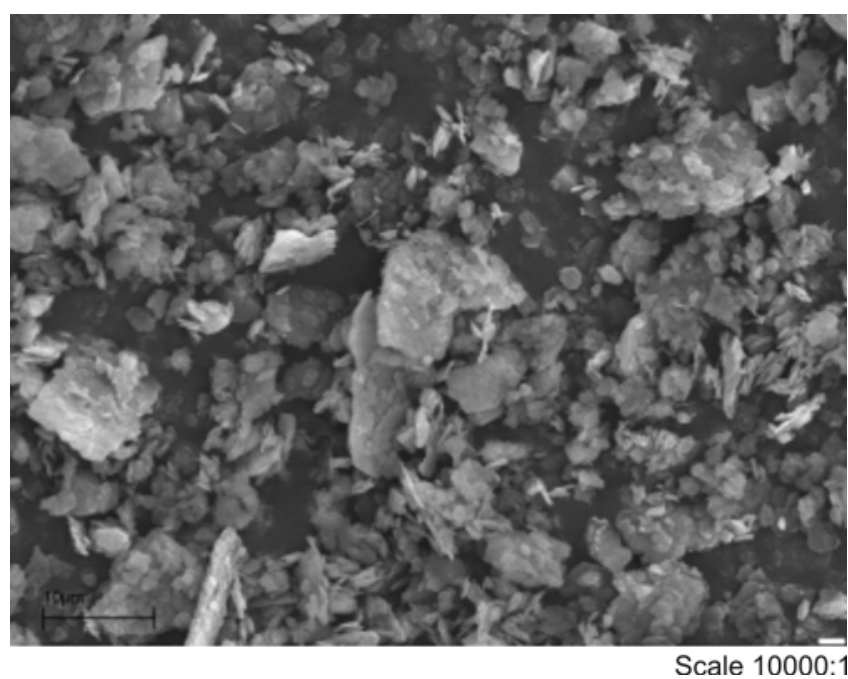

Photo 2. Kaolin modified of 3-chloropropyltrimethoxysilane

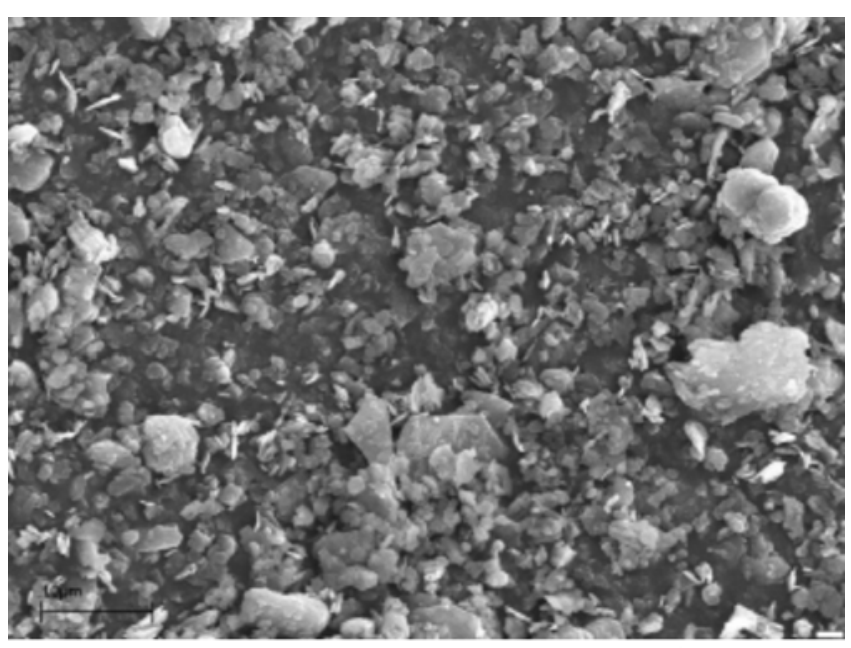

Scale 10000:1

Photo 3. Kaolin modified of 3-isocyanatepropyltrimethoxysilane

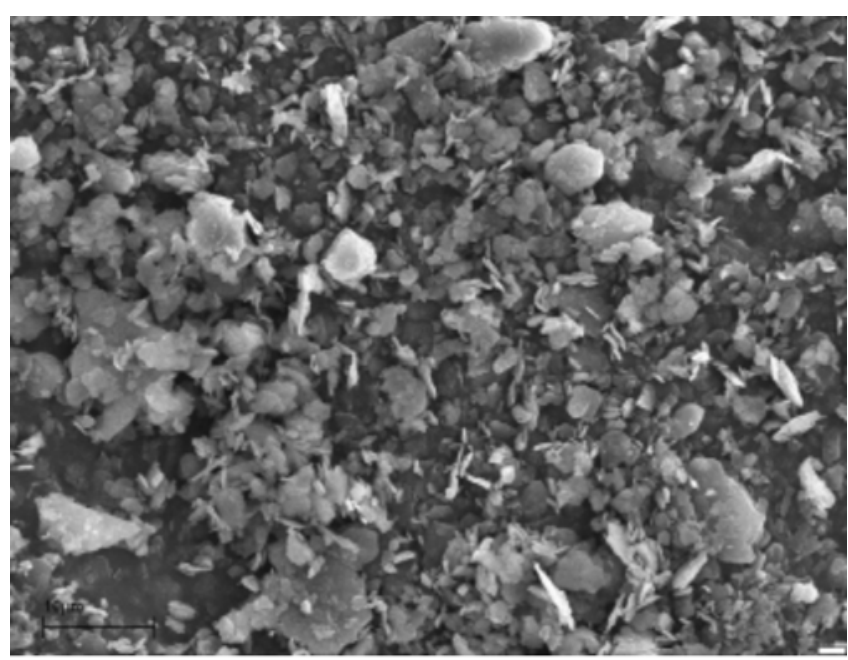

Scale 10000:1

Photo 4. Kaolin modified of 3-aminopropyltriethoxysilane

- the dehydroxylation water liberated as a result of the transition of the octahedral aluminol group to the tetrahedral aluminooxane group at temperatures ranging from 350 do $700^{\circ} \mathrm{C}$, corresponding to the temperatures of kaolin calcination,

- the chemically bound water; at about $900^{\circ} \mathrm{C}$ the remaining $\mathrm{OH}$ groups are lost leading to the formation of the aluminium-silica spinel $\mathrm{Al}_{2} \mathrm{O}_{3} \cdot \mathrm{SiO}_{2}$ and silica, 


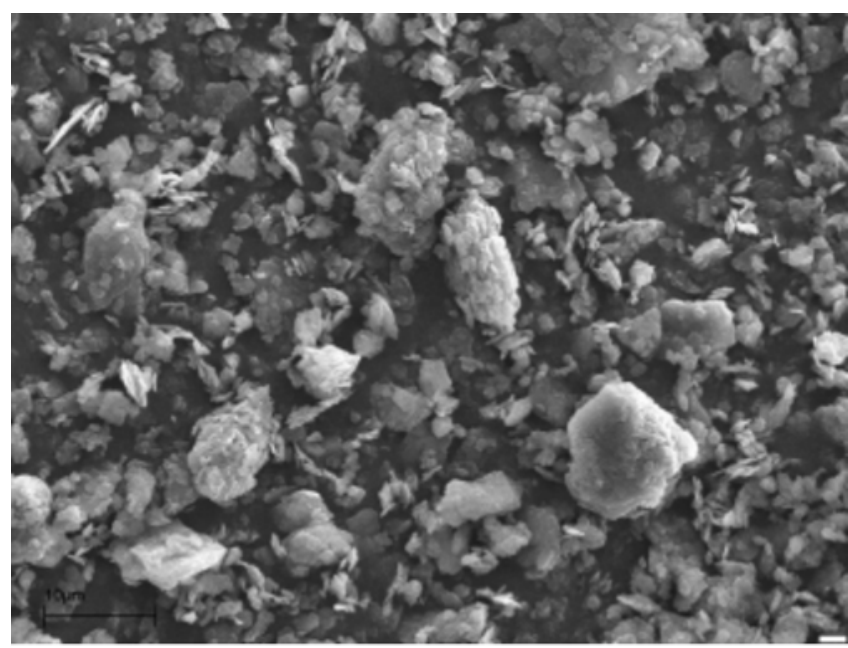

Scale 10000:1

Photo 5. Kaolin modified of N-2-aminoethyl 3-aminopropyltrimethoxysilane

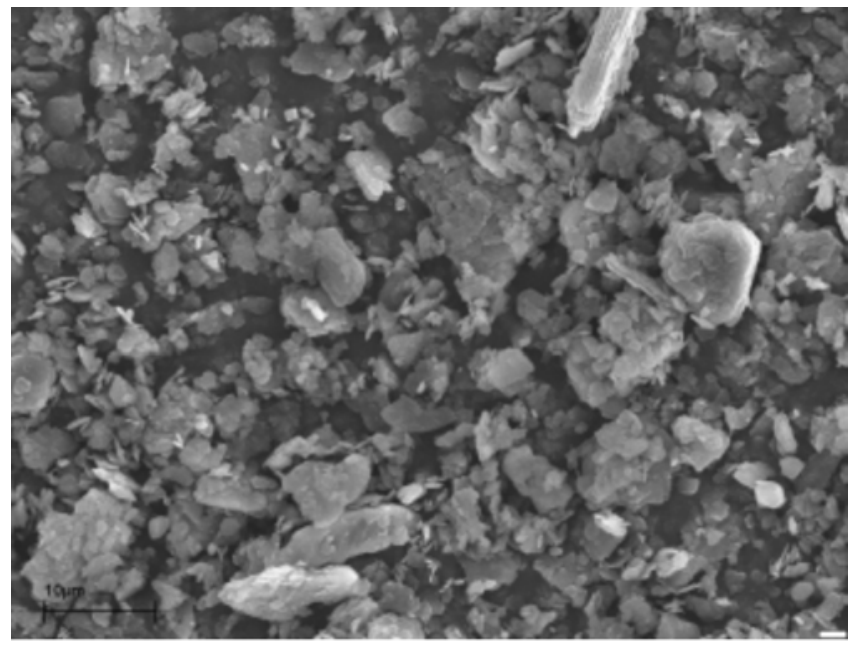

Scale 10000:1

Photo 6. Kaolin modified of 3-methacryloxypropyltrimethoxysilane

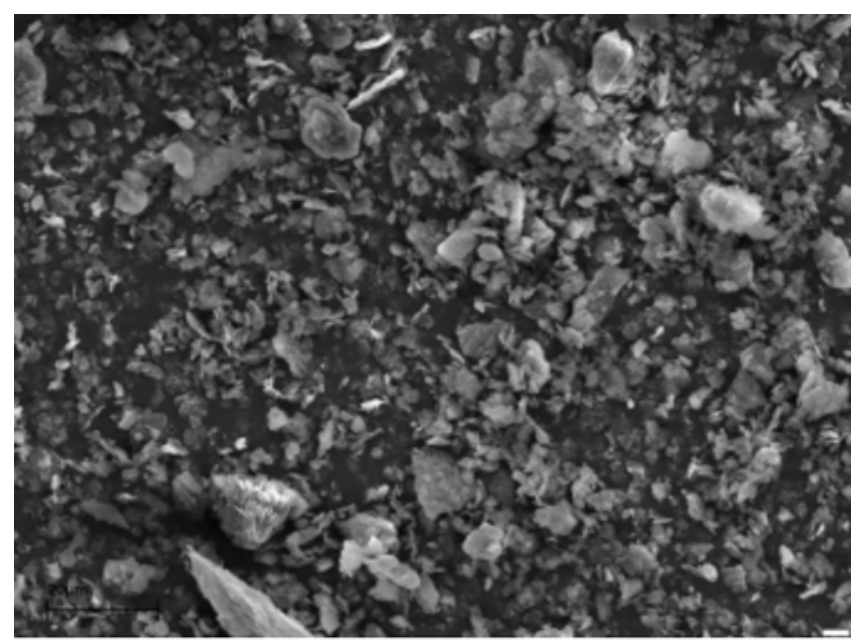

Scale 10000:1

Photo 7. Kaolin modified of vinyltriethtoxysilane

In the range of $1150-1225^{\circ} \mathrm{C}$ the spinel phase is transformed into mullite and the silica becomes cristobalite ${ }^{6}$.

The results of the FT-IR study confirm the presence of kaolinite by revealing four characteristic absorption bands, at about $3600 \mathrm{~cm}^{-1}$ assigned to the $\mathrm{OH}$ groups vibrations. The absorption bands permit the identification of the types of lamellar silicates as the spectrum of halloysite showed two bands, while those of nakrite and dyckit show three

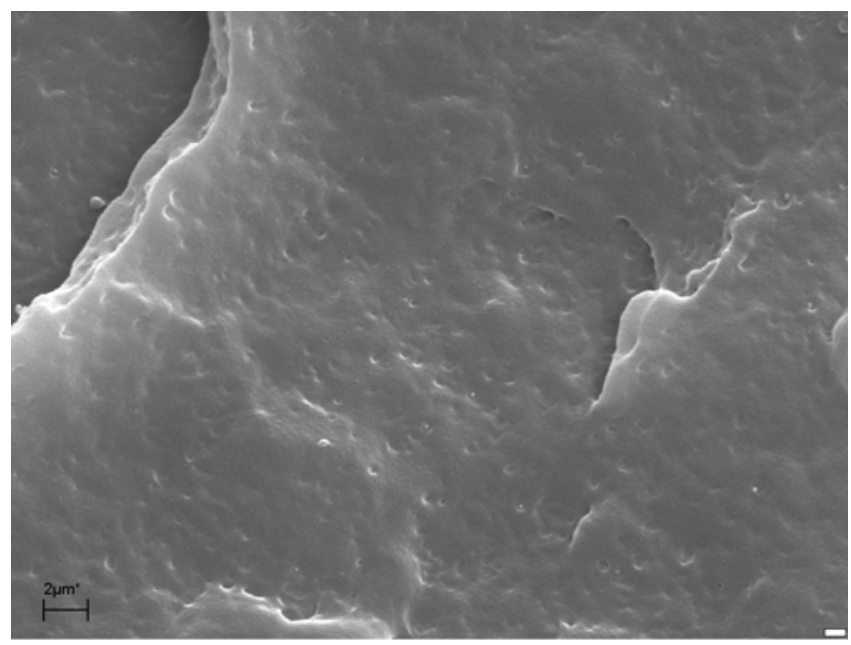

Photo 8. HDPE Hostalen

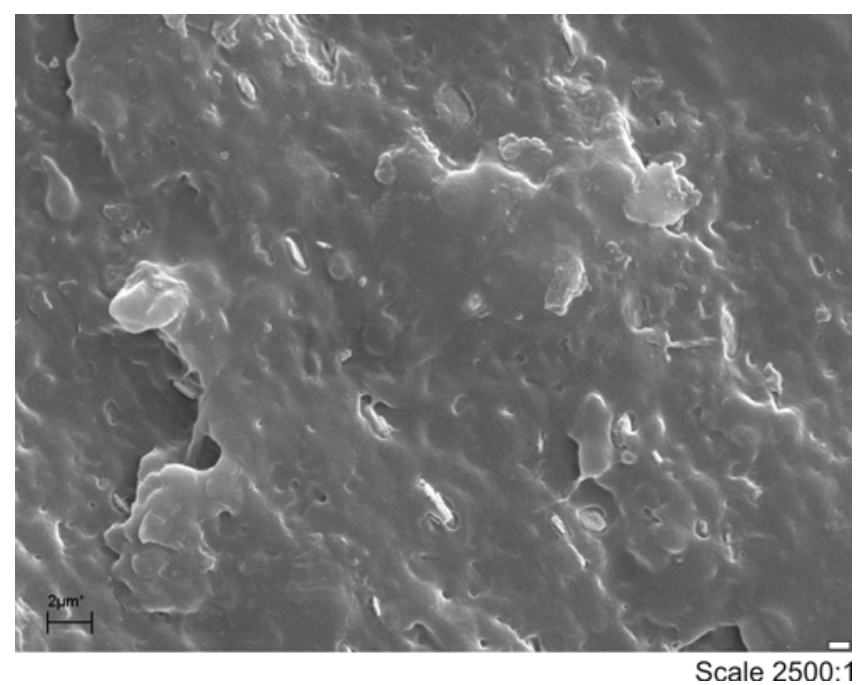

Photo 9. HDPE / pure kaolin

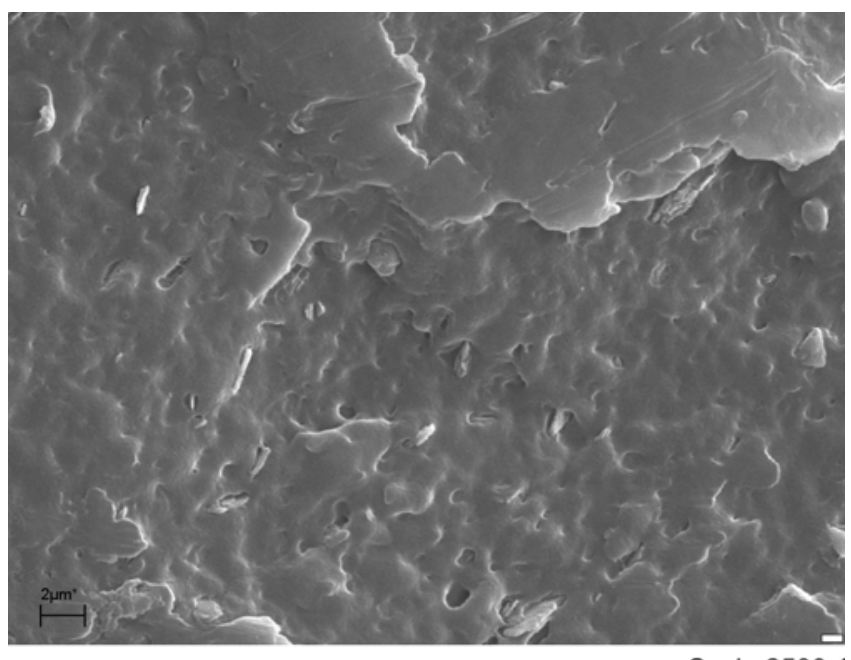

Scale 2500:1

Photo 10. Composite HDPE/ kaolin modified of 3-isocyanatepropyltrimethoxysilane

bands ${ }^{7}$. The bands, characteristic of kaolin are at 3700 and $3620 \mathrm{~cm}^{-1}$, whose presence also indicates a high degree of the system ordering 8 . At about 1680 and $1230 \mathrm{~cm}^{-1}$ there are the bands assigned to the deformation vibrations of the $\mathrm{OH}$ groups, testifying to the presence of the water bound in the aluminium silicate gallery. In the range of $900-1100 \mathrm{~cm}^{-1}$ there are the bands typical of the Si-O 


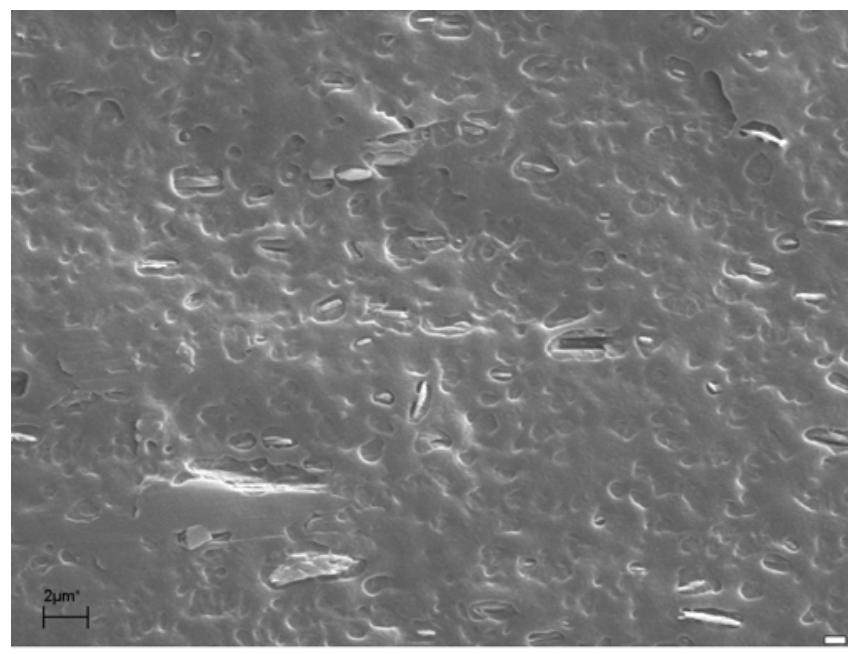

Scale 2500:1

Photo 11. Composite HDPE/ kaolin modified of 3-aminopropyltriethoxysilane

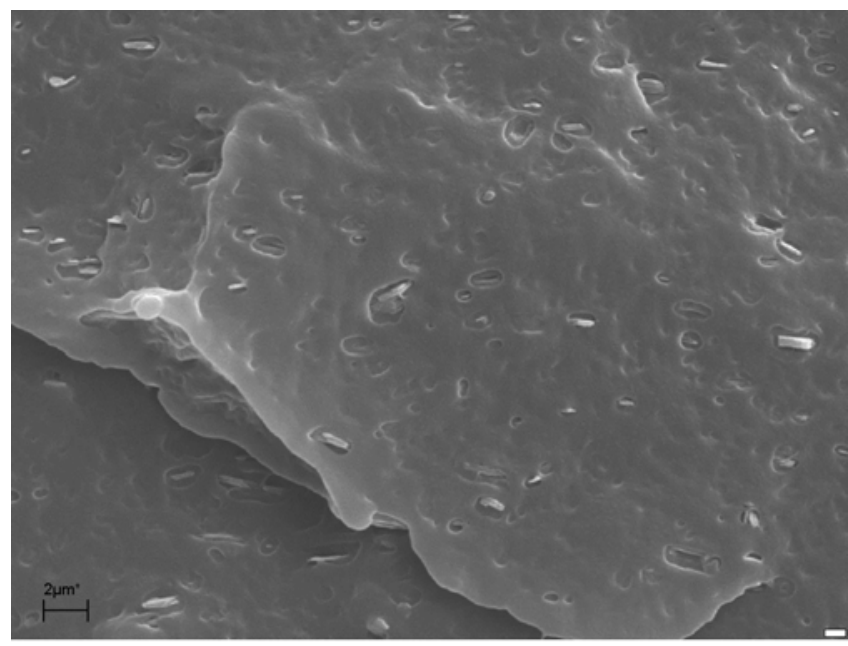

Scale 2500:

Photo 12. Composite HDPE / kaolin modified of 3chloropropyltrimethoxysilane

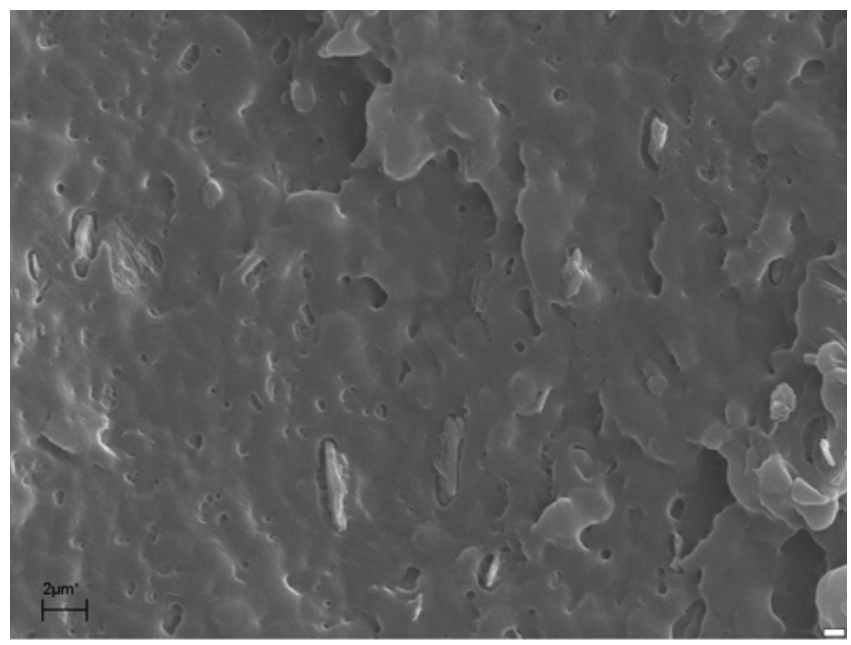

Scale 2500:1

Photo 13. Composite HDPE/ kaolin modified of $\mathrm{N}-2$ aminoethyl 3-aminopropyltrimethoxysilane

bending vibrations and the poorly separated band assigned to the Si-O stretching vibrations. A gradual decrease in the band intensity is observed above $950 \mathrm{~cm}^{-1}$, as a result of silane species adsorption on the kaolin surface ${ }^{9}$. The spectrum of kaolin modified with 3chloropropyltrimethoxysilane shows an additional band at about $800 \mathrm{~cm}^{-1}$, typical of the $\mathrm{C}-\mathrm{Cl}$ bonds. The SEM
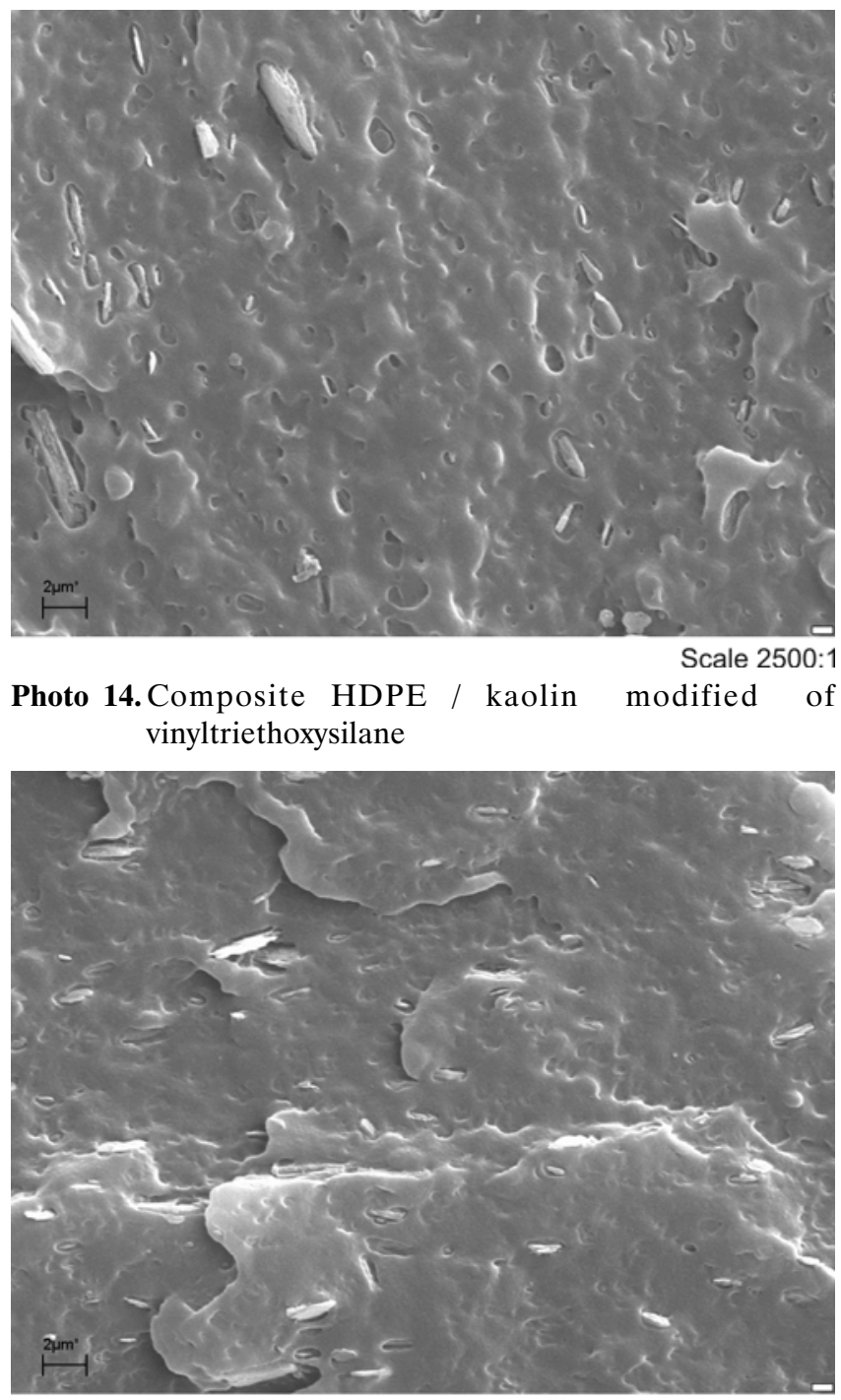

Scale 2500:1

Photo 15. Composite HDPE/ kaolin modified of 3methacryloxypropyltrimethoxysilane

photograph (Phot.1 - 7), of this filler shows the uniform size of the grains and a considerable increase in the surface area as a result of the formation of agglutinations and additional layers on the surface of the pseudo-hexagonal sheets. On the basis of the results obtained the most effective one is the modification with 3methacryloxypropyltrimethoxysilane and vinyltriethoxysilane as the use of such modified fillers has significantly improved the properties of polyethylene composites (greater hardness and elasticity modulus) with respect to those of the unfilled polymer and the polymer filled with the unmodified filler. The kaolin modification with the above two compounds also brings a correction in the physico- or mechanical parameters: the tearing strength and mean tensile stress increase, while the unit elongation on stretching and on tearing decreases. The SEM photographs of the composite (Phot. 8 -15), reveal a homogeneous distribution of the modified filler in the polymer matrix, achieved thanks to the modification improved character of the filler-polymer and filler-filler interactions. The composites filled with the modified kaolin are more stable than the unfilled polymer or the polymer filled with the unmodified kaolin. 
Table 4. The elasticity modulus and the hardness of the polyethylene composites

\begin{tabular}{|l|c|c|}
\hline Nanocomposite & Elasticity modulus [MPa] & $\begin{array}{c}\text { Hardness } \\
{\left[{ }^{\circ} \text { Sh D ] }\right.}\end{array}$ \\
\hline Pure HDPE & 1103 & 63 \\
\hline HDPE/pure kaolin & 1224 & 64 \\
\hline HDPE / kaolin Ch & 1175 & 65 \\
\hline HDPE/kaolin N2 & 1192 & 64 \\
\hline HDPE/ kaolin 3A & 1215 & 64 \\
\hline HDPE/ kaolin3iso & 1220 & 64 \\
\hline HDPE/ kaolin V & 1203 & 66 \\
\hline HDPE/ kaolin M & 1237 & 66 \\
\hline
\end{tabular}

Table 5. The mechanical parameters of the polyethylene composites

\begin{tabular}{|l|c|c|}
\hline Nanocomposite & $\begin{array}{c}\text { Mean tearing } \\
\text { stress [MPa] }\end{array}$ & $\begin{array}{c}\text { Elongation on the mean } \\
\text { tearing stress [\%] }\end{array}$ \\
\hline HDPE & $3.61 \pm 0.81$ & $17.70 \pm 2.30$ \\
\hline HDPE/pure kaolin & $3.06 \pm 0.75$ & $13.47 \pm 1.91$ \\
\hline HDPE / kaolin Ch & $24.79 \pm 20.24$ & $11.55 \pm 2.20$ \\
\hline HDPE/kaolin N2 & $40.63 \pm 1.42$ & $9.97 \pm 0.45$ \\
\hline HDPE/ kaolin 3A & $40.76 \pm 0.59$ & $9.59 \pm 0.47$ \\
\hline HDPE/ Kaolin 3iso & $32.95 \pm 17.24$ & $10.22 \pm 2.04$ \\
\hline HDPE/ kaolin V & $17.83 \pm 20.27$ & $11.96 \pm 2.94$ \\
\hline HDPE/ kaolin M & $41.27 \pm 1.78$ & $9.61 \pm 0.59$ \\
\hline
\end{tabular}

Table 6. The mechanical parameters of the polyethylene composites

\begin{tabular}{|l|c|c|}
\hline Nanocomposite & $\begin{array}{c}\text { Mean tensile } \\
\text { stress [MPa] }\end{array}$ & $\begin{array}{c}\text { Elongation on the maean } \\
\text { tensile stress [\%] }\end{array}$ \\
\hline HDPE & $38.08 \pm 1.05$ & $9.74 \pm 0.84$ \\
\hline HDPE / pure kaolin & $39.36 \pm 0.61$ & $8.37 \pm 0.35$ \\
\hline HDPE / kaolin Ch & $39.38 \pm 1.18$ & $9.59 \pm 0.30$ \\
\hline HDPE/kaolin N2 & $40.84 \pm 1.28$ & $9.62 \pm 0.40$ \\
\hline HDPE/ kaolin 3A & $41.21 \pm 0.53$ & $9.30 \pm 0.45$ \\
\hline HDPE/kaolin 3iso & $40.57 \pm 1.64$ & $9.11 \pm 0.33$ \\
\hline HDPE/ kaolin V & $40.00 \pm 1.10$ & $8.77 \pm 0.61$ \\
\hline HDPE/ kaolin M & $41.54 \pm 1.67$ & $9.24 \pm 0.53$ \\
\hline
\end{tabular}

\section{CONCLUSIONS}

The modification of kaolin fillers with silane coupling agents significantly improves their physicochemical properties and hence the properties of the obtained composites. As follows from our results, the modification of the fillers with silane coupling agents substantially improves their dispersion in the polymer matrix and hence reduces the tendency towards the agglomeration of particles, leading to a decreased strength of the filler-filler interactions and the increased strength of the filler-polymer interactions. The modified fillers are stronger bonded to the polymer which improves the physico- or mechanical parameters of the composite and permits the extension of the range of their applications.

\section{ACKNOWLEDGEMENT}

This work was supported by the Polish Scientific Committee within the framework of the grant no 3 T09A 16529

\section{LITERATURE CITED}

1. Domka, L., Krysztafkiewicz, A., Guliński, J., Urbaniak, W. \& Maciejewski H., (1997). Krzemionki i krzemiany modyfikowane krajowymi silanowymi zwiazkami proadhezyjnymi-napetniacze poliuretanów $i$ PWC, Przem. Chem.76/3, 96 - 98.

2. Akiba, E., Hayakawa, H., Hayashi, S. \& Tomura S., (1997). Structure Refinement of Synthetic Deuterated Kaolinite by Rietveld Analysis Using Time-of-Flight Neutron Powder Diffraction, Data Clays Clay Mineral 45, 781 - 788.

3. Bolewicki, A., Kubisz, J. \& Żabiński, W., (1975). Mineralogia ogólna, Wydawnictwo Geologiczne, Warszawa.

4. Jones, L. \& Atkins, P., (2004). Chemia Ogólna Czasteczki, materia, reakcje, Wydawnictwo Naukowe PWN, Warszawa.

5. Domka, L., Krysztafkiewicz, A. \& Maik, M., (1980). Przeglad reakcji grup silanolowych na powierzchni krzemionki, Chemik 33, 202 - 206.

6. Domka, L., (1983). Kaoliny jako napetniacze mieszanek gumowych, Chemik 36, $65-69$.

7. Kozłowska, A., (2005). Diagenetyczny kaolinit w piaskowcach karbonu rowu lubelskiego, Przegląd Geologiczny vol. 53, nr 3, $258-259$.

8. Office Newspaper UE L346/23.

9. Madejova, J. (2003). FT-IR techniques in claus clay mineral studies, Vibr. Spec.31, 1 - 10. 